\title{
The Comparative of Indonesian and Western Culture in Live Action: A Study of Cross-Culture
}

\author{
Bambang Nur Alamsyah Lubis ${ }^{1}$, Rakhmat Wahyudin Sagala ${ }^{2}$ \\ ${ }^{1}$ English Education Study Program, Universitas Prima Indonesia \\ ${ }^{2}$ English Education Study Program, University of Muhammadiyah Sumatera Utara \\ bambangnuralamsyahlubis@unprimdn.ac.id
}

\begin{tabular}{cll}
\hline \multicolumn{1}{c}{ ARTICLE INFO } & & \multicolumn{1}{c}{ ABSTRACT } \\
\cline { 1 - 1 } Received & & This study deals with cross-culture of people who live in Indonesia \\
Revised & & and western. Especially, the national culture of Indonesia that is going \\
$09 / 06 / 2020$ & & to compare with western culture. People know that every country has its \\
Accepted & & own culture, the eastern and western countries have their way of going \\
$18 / 07 / 2020$ & & live. The aim of this study is to compare the culture of Indonesia and \\
& western people in their daily live. This study used descriptive \\
Keywords: & qualitative method. This study analysed the utterances, actions and \\
cross-culture, & the way of life Indonesia and western people. The result, there are \\
Indonesian & many significant different ways of life, utterance, and action that \\
culture, Western & actually allowed in Indonesia but forbidden in western people. \\
culture, compare, &
\end{tabular}

different.

How to cite: Lubis, B. N. A., Sagala, R. W. (2020). The Comparative of Indonesian and Western Culture in Live Action: A Study of Cross-Culture. English Teaching and Linguistics Journal, 1(2), 56-59.

\section{INTRODUCTION}

Indonesia is one of the bigger countries in Asia. Many kinds of cultural backgrounds grow fast and old. It comes from a very old tradition that was influenced by the new generation. The new generation actually must be understood about their cultural background. But this case, we do not want to discuss specific cultures in Indonesia, but this study will discuss the national culture of Indonesia that is going to compare with western culture. People know that every country has its own culture, the eastern and western countries have their way of going live. Many kinds of characteristics, values, beliefs, and behavior of a country different from another.

Grant and Lei (in Sugirin: 2009), claim that cultural differences are the main issues in cross-cultural education. Different cultural is going to show the uniqueness of a country. Culture is not only about characteristics, values, beliefs, and behavior, but it is also about the language, specifically the use of language itself. People study about cross-culture to make sure among of human that has different nationalism do not misunderstand when they meet in one condition, or when visiting into another country that has a different culture with the visitor.

Actually why people need to discuss cross-culture? The very correct answer is to help people acquire attitudes, knowledge, and skills needed to successfully function within their micro-culture, mainstream culture, and the global community, that purpose of it is to make people realize they are not live alone on the world, but still many people that have own way in life. And then, the rest, why we need to study about cross-culture, Mulyana (2005) says that the failure of communication often arouses misunderstanding, financial loss, and even great disaster. 
Human communication is very important, that is way cross-culture study function to ignore the misunderstanding about communication. Communication is a basic way of human life. That is why the study about cross-culture is to know the way of doing communication when meeting a new environment. Mulyana (2005) our success in communication depends on how far we understand others' feedback. Based on that case, we can see, how difficult communication among people different cultures. It can be imagined how difficult communication can be if the source and receiver are in different contexts and share a few symbols (Jant: 2001).

Study about cross-culture, several competencies need to know. The following are the stages learners must go through to achieve this competence:

1. Cross-Cultural Knowledge (CCK), it is a prerequisite for cross-cultural understanding. The inability to appreciate other cultures often stems from the absence of knowledge about them. Respect and appreciation of culture will happen and grow if people are familiar with the respected characteristics, values, beliefs, and behaviors in the culture.

2. Cross-Cultural Awareness (CCA), it shows understanding and appreciation, which may be accompanied by changes in behavior and attitudes towards the culture.

3. Cross-Cultural Sensitivity (CCS), the ability to read into situations, contexts, and behaviors that are culturally rooted and be able to react to them appropriately. A suitable response necessitates that people no longer carry their own culturally determined interpretations of the situation or behavior (i.e. good/bad, right/wrong) which can only be nurtured through both cross-cultural knowledge and awareness.

4. Cross-Cultural Competence (CCC). $\mathrm{CCC}$ is the final stage of cross-cultural understanding and signifies the actor's ability to work effectively across cultures. In Ross and Thornson's words, it is the development of knowledge and skills through experience in cultural differences to create a cultural synergy that leads to the development of crosscultural competence (Ross \& Thornson, 2008).

Study about cross-culture, many things that need to learn by people. Because learning about other cultures must notice some elements. The purpose of it, to make learners easy to understand about a specific culture. Brown (1995) summarized the elements or visible attributes of culture as follows:

1. Artifacts: the physical things that are found that have particular symbolism for a culture, or they can also be more everyday objects, such as the bunch of flowers in reception. The main thing is that they have special meaning, at the very least for the people in the culture.

2. Stories, histories, myths, legends, jokes, with a typical story to include a bad guy and a good guy (often the founder or a prototypical cultural member). There may also be an innocent and guilty figure, etc. Sometimes the stories are true, at other times nobody knows.

3. Rituals, rites, ceremonies, celebrations (processes or sets of actions which are repeated in specific circumstances and with specific meaning). They may be associated with company events such as the release of a new event.

4. Heroes or named people who act as prototypes, or idealized examples, by which cultural members learn of the corrector 'perfect' behavior.

5. Symbols and symbolic action. Symbols, like artifacts, are things that act as triggers to remind people in the culture of its rules, beliefs, etc. They can also be used to indicate status within a culture. This includes clothing, office decor, and so on.

6. Beliefs, assumptions, and mental models. An organization and culture will often share beliefs and ways of understanding the world. This helps smooth communications and agreement, but can also become fatal blinkers that blind everyone to impending dangers. (the external displays of underlying beliefs that people use to signal to other people of their membership).

The Comparative of Indonesian and Western Culture in Live Action: A Study of Cross-Culture (Lubis, B.N.A) 
7. Rules, norms, ethical codes, values. The norms and values of a culture are effectively the rules by which its members must abide or risk rejection from the culture (which is one of the most feared sanctions known).

\section{METHODS}

This study was conducted by applying a qualitative research design. The data of this research is utterance, action, and way of life in Indonesia and western people. The source of this research is Indonesia and western people. The instrument of data collection in this research is video-recorder.

\section{RESULT AND DISCUSSION}

Indonesia and western people are different to respond to some questions. About these questions, in Indonesia these questions are normal to be asked, whomever they can be asked, even they are not too close or not the family member. But for western people, these questions are impolite and need to avoid.

\section{"Have you get married?"}

This question is not a big deal for Indonesia people, because marriage status is very important for people that stay in Indonesia. Marriage status is something that needs to inform everybody. Because this status is a benchmark of happiness in life. But, for western people, this question must be avoided. Because marriage status is not to be published. Marriage status is about a personal problem. They can stay together even they do not get married.

\section{"What is your job?"}

Job is something important. Everybody wants a good job, in Indonesia, everybody wants to tell and shows their job. That is why, in Indonesia, this question is normal to be asked. No matter what kinds of job they have, they will tell about it clearly and specific, but it is forbidden to ask, for western people. It means that it is impolite to be asked, it is about personal life that cannot be touched by anybody. Western people feel uncomfortable with that question.

"How old are you?"

This question is also a normal question to be asked in Indonesia. Because in Indonesia to make sure we are going to act polite to call someone, we need to ask the age. It means that if the listener is older than the speaker, the speaker will use specific called to the listener. Such as "kakak", "abang", "ibu" or "bapak". It is the purpose of Indonesian asks about age. And no matter what is your gender, male or female. But, in the western case is quite different. Asking a man's age is not a big deal for them, but asking a woman's age is a bad deal to do. Because it is impolite to ask woman age in western. Asking a woman age, means you do not respect them, you are disturbing their privacy, and it will raise their perspective about you are not a good man to befriend.

\section{"What is your religion?"}

This question is very sensitive to be asked in western. It is about human belief. And if you ask them about that question, in their mind, you are racist. It means that you are not good to be friends, to be close and good enough to continue the communication. Because some of them have not religion. That is why this question is not allowed to be asked. It is quite different in Indonesia. It is a normal question to be asked. Why Indonesian ask about religion? The purpose of it to make sure we are not wrong to do something. For instance, we are no going to disturb their time to pray and more respect to other people that different religions with us.

Another different culture that needs to compare Indonesia and western is the way to invite someone to the party. When Indonesia made a party, they will send the invitation card to everybody that we do not know exactly they are going to come or not. And the number of invitations cards are more than a hundred, sometimes thousands. But it is quite different from 
the way western people invite the guest into their party. They send the letter only to people who close with them and after receiving the invitation, the guest must be given an exact answer if they are going to come or not. The second way is, the host will come to meet the guest and tell she/he will make a party and ask the guest to come to the party or not. And the guest must be given direct questions about their standing. Why it is different? At the first time Indonesian culture said that, if many guests come to the party, it means the host has a big family, popular, someone has a high level in society, functionary, or someone very important. And they do not care the food is enough or not, the important thing is many guests come to the party. It is different from western people no matter who is the host, the host only serves the guest suitable with a guest that has confirmed to come to the party. They are not allowed people who are not invited to the party and who have rejected the invitation to come and enjoy the party because they have been ready food, beverage, a seat for people that have accepted the invitation.

\section{SUGGESTION AND CONCLUSION}

Culture is something unique in each region, it adds the beautifulness of human life interaction. This study was comparing two models of culture, Indonesia, and western culture. The purpose of this study is because Indonesian people learn English as a Foreign Language, and many kinds of university open the English literature and Education program. That is why this study is purposed to people or students who learn English as their study program. Indonesia and western culture are specifically different, such as ways of life, utterance, and action that allowed in Indonesia but forbidden in western people.

\section{REFERENCES}

Brown, A. (1995). Organizational Culture. London: Pitman.

Jant, F. E. (2004). An Introduction to Intercultural Communication. London: Sage Publication.

Mulyana, D. (2005). Komunikasi Efektif. Bandung: Rosdakarya.

Neulip, J. W. (2009). Intercultural Communication: A Contextual Approach. Los Angeles: Sage Publication.

Peoples, J., \& Bailey, G. (2009). Humanity: An Introduction to Cultural Anthropology. Wadsworth: Wadsworth, Cengage Learning

Ross, K. G. \& Thornson, C. A. (2008). Toward an Operational Definition of Cross-Cultural Competence from Interview Data. Florida: University of Central Florida.

Scolon. \& Scolon. (1995). Intercultural Communication. Oxford: Blackwell Publisher.

Sharifian, F. \& Palmer, G. B. (2007). Applied Cultural Linguistics Implications for Second Language Learning and Intercultural Communication. Amsterdam/Philadelphia: John Benjamins Publishing Company.

Sinagatullin, I. M. (2003). Constructing Multicultural Education in a Diverse Society. London: The Scarecrow Press, Inc.

Sugirin. (2009). Cross-Cultural Understanding: what every efl teacher should know. Yogyakarta: Indonesia

Williams, G. (2010). ESL Teaching: How Language and Culture are Interdependent. Language Study. November 2010.

Wardhaugh, R. (1988). An Introduction to Sociolinguistics. Oxford: Blackwell Publishers. Students' report in Class of Sociolinguistics II

The Comparative of Indonesian and Western Culture in Live Action: A Study of Cross-Culture (Lubis, B.N.A) 